\title{
PENERAPAN SISTEM MANAJEMEN MUTU ISO 9001 PADA KONTRAKTOR PT. X
}

\author{
Arief Darmawan ${ }^{1}$, Sidiq Wacono ${ }^{2}$, Jonathan Saputra ${ }^{3}$ \\ 1,2,3 Jurusan Teknik Sipil, Politeknik Negeri Jakarta, Jl. Prof. Dr. G. A Siwabessy, Kampus UI, Depok, \\ Jawa Barat 16425. \\ e-mail: ariefdarmawan10@ymail.com ${ }^{1}$, sidiq.wacono@ sipil.pnj.ac.id ${ }^{2}$, jonathan.saputra@ sipil.pnj.ac.id ${ }^{3}$
}

\begin{abstract}
Infrastructures development in Indonesia is experiencing a high increase. However, many construction failures were due to construction that was not following the predetermined quality. Data obtained from the Investigation of the PNK Technical Team in 2013 contained 5 cases of construction project failure handled by the authorities with a total loss of more than 5 billion to the state. The reality shows that many construction service businesses have names but do not have the supporting facilities. Therefore, data collection aims to analyze the application of the ISO 9001: 2015 application quality management system and its application constraints. Processing data use descriptive statistical analysis and using SPSS version 25 software. The data testing techniques used include validity, reliability, and descriptive hypothesis. The data was collected using a questionnaire method for construction employees in the Design Project for the Tanjung Barat Station Flats. This analysis indicates that the application of the ISO 9001: 2015 quality management system by taking into account all the points from clause 4 to clause 10 is $85.19 \%$ and is in the excellent category (80-100\%). Factors that become obstacles in implementing ISO 9001: 2015 are due to the lack of socialization regarding the application of ISO 9001, documented information, and communication between project teams.
\end{abstract}

Keywords : ISO 9001; ISO 9001:2015; Quality Management System.

\begin{abstract}
ABSTRAK
Perkembangan infrastruktur di Indonesia sedang mengalami peningkatan yang tinggi. Tetapi, banyak ditemui kegagalan konstruksi yang disebabkan oleh pelaksanaan konstruksi yang tidak sesuai dengan kualitas yang sudah ditetapkan. Data yang diperoleh dari Investigasi Tim Teknis PNK pada tahun 2013 menunjukkan 5 kasus kegagalan proyek konstruksi yang ditangani pihak berwajib dengan nilai kerugian negara mencapai lebih dari 5 milyar. Kenyataan menunjukkan banyak usaha jasa konstruksi yang memiliki nama tetapi tidak memiliki fasilitas yang mendukung. Oleh karena itu, dilakukan pengambilan data yang bertujuan untuk menganalisis penerapan sistem manajemen mutu ISO 9001:2015 dan faktor kendala dalam penerapannya. Pengolahan data menggunakan uji hipotesis deskriptif dan menggunakan bantuan software SPSS versi 25. Teknik pengujian data yang digunakan meliputi uji validitas, uji reliabilitas dan hipotesis deskriptif. Pengumpulan data dilakukan menggunakan metode kuesioner terhadap karyawan konstruksi yang terlibat dalam Proyek Rancang Bangun Rumah Susun Stasiun Tanjung Barat. Hasil analisis ini menunjukkan bahwa penerapan sistem manajemen mutu ISO 9001:2015 dengan memperhatikan seluruh butir dari klausul 4 sampai klausul 10 adalah sebesar 85,19\% dan masuk kategori sangat baik (80-100\%). Faktor yang menjadi kendala dalam penerapan ISO 9001:2015 adalah akibat kurangnya sosialisasi mengenai penerapan ISO 9001, informasi terdokumentasi, dan komunikasi antar tim proyek.
\end{abstract}

Kata kunci : ISO 9001; ISO 9001:2015; Sistem Manajemen Mutu.

\section{PENDAHULUAN}

Manajemen sebagai sebuah proses
perencanaan, perorganisasian,
pengkoordinasian, dan pengontrolan
sumber daya untuk mencapai sasaran
secara efektif dan efisien [1]. Efektif berarti bahwa tujuan dapat dicapai sesuai dengan perencanaan, sementara efisien berarti bahwa tugas yang ada dilaksanakan secara benar, terorganisir dan sesuai dengan jadwal [2]. Proyek merupakan serangkaian aktivitas atau 
tugas yang memiliki tujuan spesifik yang harus dicapai dengan spesifikasi tertentu, memiliki tanggal mulai dan selesai, memiliki keterbatasan biaya, memerlukan sumber daya manusia dan non-manusia, dan kegiatan multifungsi [3]. Konstruksi adalah suatu kegiatan membangun sarana maupun prasarana yang meliuputi pembangunan gedung (Building Construction), pembangunan prasarana sipil (Civil Engineer), dan instalasi mekanikal dan elektrikal [4]. Pengertian mutu ditinjau dari definisi strategik menyarankan bahwa mutu adalah segala sesuatu yang mampu memenuhi keinginan atau kebutuhan pelanggan. Yang dimaksud dari sistem manajemen mutu yaitu merupakan sekumpulan prosedur terdokumentasi serta praktik-praktik standar untuk manajemen sistem yang bertujuan menjamin kesesuaian dari suatu proses dan produk (barang/jasa) terhadap kebutuhan dan persyaratan tertentu [5]. Berdasarkan data Dinas Penanggulangan Kebakaran dan Penyelamatan DKI Jakarta menunjukkan dari 780 hanya 558 gedung yang memenuhi persyaratan keamanan pada akhir 2017. Sisanya, sebanyak 28\% bangunan gedung yang ada di Jakarta tergolong tak aman, bahkan mampu menyebabkan kegagalan bangunan. Hal ini ditimbulkan akibat kurangnya penerapan sistem manajemen mutu dalam proses konstruksi [6]. Pengendalian mutu adalah aktivitas yang berorientasi pada tindakan pencegahan kerusakan, dan bukan berfokus pada upaya mendeteksi kerusakan saja [7]. Pengendalian mutu yang dimaksud adalah menggerakkan siklus PDCA, yaitu melakukan Plan (perencanaan), Do (pelaksanaan), Check (pemeriksaan) dan Act (tindakan) untuk menemukan danmemecahkan persoalan yang ditemukan. Hakikatnya siklus PDCA adalah suatu metode untuk melakukan perbaikan secara berkelanjutan [8]. Tujuan ISO secara umum adalah memfasilitasi perjanjian kesepakatan global dalam standard mutu internasional [9]. ISO sendiri mempunyai pengertian yaitu koordinasi standar kerja internasional, publikasi standar harmonisasi internasional, dan promosi pemakaian standar internasional [10]. Penerapan sistem manajemen mutu ISO memiliki efek yang menguntungkan pada hasil proses, menurunnya tingkat kesalahan dan meningkatkan kontrol manajemen [11]. Oleh karena itu, ISO 9001 merupakan standar manajemen mutu yang membantu sebuah perusahaan atau organisasi untuk dapat bekerja secara efisien dan meningkatkan kepuasan pelanggan [12]. Walaupun penerapan sistem manajemen mutu yang digunakan sudah diakui secara internasional, tetapi ada beberapa faktor yang menyebabkan penerapan ISO 9001 tidak berjalan mulus [13]. Sehingga, ISO 9001:2015 lebih mengatur kriteria untuk sistem manajemen mutu dan mulai merambah ke manajemen risiko dimana organisasi nantinya diminta mengadopsi prinsip manajemen risiko seperti risk and opportunities, risk avoidance, risk mitigation, dan risk acceptance [14]. Oleh sebab itu, diperlukan kajian mendalam untuk mengidentifikasi dan menganalisa penerapan sistem manajemen mutu dan faktor kendala dalam penerapannya pada proyek konstruksi.

\section{METODE PENELITIAN}

Penelitian ini dilakukan pada Proyek Rancang Bangun Rumah Susun Stasiun Tanjung Barat. Metode yang dilakukan pada penelitian ini merupakan metode berita umum. Metode berita umum yang dilakukan menggunakan cara proses observasi, wawancara tidak terstruktur dan penyebaran kuesioner terhadap 30 responden terkait penerapan sistem manajemen mutu ISO 9001:2015 yang sudah berkontribusi secara eksklusif dilapangan dalam Proyek Rancang Bangun Rumah Susun Stasiun Tanjung 
Barat. Proses pengambilan data dilakukan pengisian kuesioner evaluasi yang dibagikan pada pihak yang terlibat pada penerapan sistem manajemen mutu. Penentuan variabel pada kuesioner berpedoman dalam tinjauan sistem manajemen mutu. Kuesioner diuji untuk pertanda validitas dan reliabilitas instrumen penelitian. Data yang diperoleh lantas dianalisis dengan menggunakan uji hipotesis deksriptif.

Berikut adalah langkah - langkah menghitung penerapan sistem manajemen mutu [15]:

1. Menghitung Total Skor Responden

2. Menghitung Total

3. Skala Tertinggi Setiap Klausul (SY)

4. Menghitung Skala Terendah Setiap Klausul $(S X)$

5. Menghitung masing - masing persentase dari responden

6. Mencari persentase Index untuk masing - masing topik

Pengujian pengaruh penerapan sistem manajemen mutu ISO 9001:2015 untuk proses analisis data menggunakan bantuan program perhitungan statistik SPSS versi 25. Adapun uji yang dilakukan dalam penelitian ini meliputi:

1. Uji Validitas

Syarat minimum untuk dianggap suatu butir instrumen valid adalah nilai indeks validitasnya $\geq 0,3$.

\section{Uji Reliabilitas}

Uji reliabilitas adalah sejauh mana hasil pengukuran dengan menggunakan objek yang sama, akan menghasilkan data yang sama [15].

\section{Hipotesis Deskriptif}

Hipotesis deskriptif merupakan jawaban sementara terhadap masalah deskriptif, yaitu yang berkenaan dengan variabel mandiri [16].

Untuk mencapai tujuan, maka keseluruhan kegiatan penelitian dirancang sesuai dengan diagram alir seperti terlihat pada Gambar 1.
Tahap awal dimulai dengan persiapan menentukan lokasi penelitian dan data yang diperlukan. Lalu, peneliti melakukan pengumpulan data penelitian dengan cara observasi, wawancara, penyebaran kuesioner, data umum dan data teknik proyek. Setelah itu dilakukan pengolahan data dengan analisa statis deskriptif dan analisa perhitungan statistik sehingga didapat data akhir yang dapat dibuat kesimpulan dan juga saran.

\section{HASIL dan PEMBAHASAN}

Untuk analisis penerapan sistem manajemen mutu ISO 9001:2015 output kuesioner dilakukan pada bentuk skoring skala Likert. Penilaian diberikan dalam setiap pertanyaan menurut klausul 4 hingga klausul 10.

Untuk hasil perhitungan didapat dari:

1. Menghitung penilaian/skoring skala likert

Total $R 1=(3 \times 5)=15$

Kemudian lakukan langkah yang sama untuk menghitung R2 sampai R30.

2. Menghitung total (v)

$$
\begin{aligned}
& \text { Total }=15+13+11+\ldots+13+14 \\
& +12=370
\end{aligned}
$$

3. Menghitung jumlah skor tertinggi (vi) Skor tertinggi $=(5 \times 3)=15$

4. Menghitung jumlah skor minimal (vii)

Skor terendah $=\left(\begin{array}{lll}1 & \mathrm{X} & 3\end{array}\right)=3$

5. Menghitung presentase jumlah penerapan masing - masing responden (viii)

$\%$ Penerapan R1 = $\frac{15}{15} \times 100 \%=$ $100 \%$

Kemudian lakukan langkah yang sama untuk menghitung R2 sampai R30

6. Menghitung presentase indeks setiap klausul 
$\% \quad$ Indeks
$\frac{100 \%+86,67 \%+\cdots+93,33 \%+80 \%}{30} \times 100 \%=$ $82,22 \%$

Maka dihasilkan persentase untuk klausul 4 adalah sebanyak 82,22\% dengan keterangan skala sangat baik.

Gambar 2 menampilkan gambar diagram radar chart berdasarkan perhitungan output pengolahan kuesioner masing masing klausul dalam Proyek Rancang Bangun Rumah Susun Stasiun Tanjung Barat oleh PT. Brantas Abipraya menggunakan masing - masing klausul mempunyai nilai sebagai berikut:

1. Klausul $4=82,22 \%$

2. Klausul $5=85 \%$

3. Klausul $6=84 \%$

4. Klausul $7=83,78 \%$

5. Klausul $8=86,67 \%$

6. Klausul $9=88 \%$

7. Klausul $10=86,67 \%$

Karakterikstik Responden

a. Berdasarkan Jenis Kelamin

Dari Gambar 3 memberitahukan bahwa didalam tim proyek ada $97 \%$ berjenis kelamin laki - laki dan 3\% responden berjenis kelamin perempuan.

b. Berdasarkan Pengalaman Kerja

Dari Gambar 4 memberitahukan bahwa 53\% responden memiliki pengalaman kerja $1-2$ tahun, $27 \%$ responden memiliki pengalaman kerja 3 - 4 tahun, dan 20\% responden memiliki pengalaman kerja lebih dari 5 tahun.

c. Berdasarkan Tingkat Pendidikan Terakhir

Dari Gambar 5 diatas memberitahukan bahwa $33 \%$ responden berpendidikan SMA, 20\% responden berpendidikan D3, dan $47 \%$ responden berpendidikan $\mathrm{S} 1$.

d. Berdasarkan Divisi

$\begin{array}{lcr}\text { Dari Gambar } & 6 & \text { diatas } \\ \text { memberitahukan bahwa } & 3,3 \% \\ \text { responden menjabat di bagian } & \text { Site }\end{array}$

Administration Manager, 3,3\% responden menjabat di bagian Site Engineer Manager, 3,3\% responden menjabat di bagian Site Operation Manager, 6,7\% responden menjabat di bagian Site Manager, $10 \%$ responden menjabat di bagian Quality Control, $30 \%$ responden menjabat di bagian Engineer, 13,3\% responden menjabat di bagian Operasional, dan $13,3 \%$ responden menjabat di bagian Pelaksana.

\section{Uji Penelitian}

Uji Validitas

Hasil uji validitas bisa ditinjau dalam Tabel 1. Dari output uji validitas diperoleh angka Pearson Correlation pada tiap nomor butir pertanyaan lebih besar berdasarkan taraf signifikansinya. Dengan demikian bisa dikatakan variabel penerapan sistem manajemen mutu ISO 9001:2015 mempunyai kriteria valid untuk seluruh item pertanyaan, hal ini memperlihatkan masing - masing pertanyaan dalam variabel ini layak diajukan menjadi penelitian lebih lanjut.

Uji Reliabilitas

Hasil uji reliabilitas bisa dicermati dalam Tabel 2. Dari output uji reliabilitas diperoleh angka Cronbach's Alpha sebanyak 0,687 dibandingkan menggunakan koefisien output untuk variabel sistem manajemen mutu ISO 9001:2015 sebanyak 0,687>0,361 $\left(r_{\text {hitung }}>r_{\text {tabel }}\right)$. Dapat disimpulkan bahwa instrumen penelitian terbukti reliabel lantaran koefisien reliabilitas pengujian lebih besar daripada koefisien reliabilitas tabel.

\section{Hipotesis Deskriptif}

Dengan memperhatikan nilai persentase penerapan semua butir menurut klausul 4 hingga klausul 10 dan memakai rentang nilai terendah menurut kategori interpretasi penerapan yaitu 81 , maka rumusan hipotesisnya menjadi berikut:

Penerapan Sistem Manajemen Mutu 
Ho : Nilai penerapan sistem manajemen mutu tidak ada perbedaan yang signifikan, sehingga dapat disebut bahwa $\mu=81$.

Ha : Nilai penerapan sistem manajemen mutu ada perbedaan yang signifikan, sehingga dapat disebut bahwa $\mu \neq 81$.

Didapat nilai mean dari perhitungan statistik sebesar 85,1914 seperti pada Tabel 3.

Meski tidak selaras menggunakan 81 sebagai nilai yang dihipotesiskan, dipandang menurut nilai t-hitung yang didapat adalah 5,484 misalnya ada dalam gambar 8 dan untuk nilai t-tabel menggunakan $\mathrm{df}=6$ dan $\alpha=0,05$ adalah 1,943. Sehingga didapat menurut output perhitungan statistik bahwa t-hitung $>\mathrm{t}-$ tabel, Ho ditolak dan $\mathrm{Ha}$ diterima, terdapat perbedaan yang signifikan sampai bisa diklaim bahwa $\mu \neq 81$. Hasil nilai menurut One-Sample Statistics bisa dipandang dalam Tabel 3. Didapat nilai signifikansi adalah 0,002 menggunakan nilai test value $=81$, nilai $\alpha=0,05$ lantaran selang kepercayaan yang dipakai merupakan 95\%. Dilihat menurut output perhitungan statistik bahwa nilai sig < $\alpha$, maka Ho ditolak dan Ha diterima, terdapat perbedaan yang signifikan sampai bisa diklaim bahwa $\mu$ $\neq$ 81. Hasil nilai menurut One-Sample Test bisa dipandang dalam Tabel 4 .

\section{KESIMPULAN}

Dari output analisis penerapan sistem manajemen mutu ISO 9001:2015 dalam Proyek Rancang Bangun Rumah Susun Stasiun Tanjung Barat bisa disimpulkan, bahwa:

1. Tingkat penerapan sistem manajemen mutu ISO 9001:2015 PT. Brantas Abipraya dalam Proyek Rancang Bangun Rumah Susun Stasiun Tanjung Barat sebanyak 85,19\% dievaluasi sangat baik (81\%-100\%)

2. Faktor yang menjadi hambatan pada penerapan sistem manajemen mutu
ISO 9001:2015 adalah kurang maksimalnya sosialisasi secara lisan tentang penerapan sistem manajemen mutu ISO 9001:2015, kurangnya informasi terdokumentasi lantaran hilang maupun terlewat, dan kurangnya komunikasi antar tim proyek sebagai akibatnya hal ini bisa menghambat tercapainya tujuan penerapan sistem manajemen mutu ISO 9001:2015 yang efektif dan efisien.

Penelitian ini bisa memberikan informasi pada pihak kontraktor supaya dapat memperhatikan hal - hal yang dapat meningkatkan kedisiplinan seluruh karyawan konstruksi agar penerapan sistem manajemen mutu ISO 9001:2015 bisa maksimal. Pada penelitian ini, penulis mempunyai keterbatasan waktu dan mengalami hambatan pada pengambilan data. Penulis menyarankan untuk penelitian selanjutnya bisa menggunakan penelitian ini menjadi referensi, menggunakan metode, atau contoh penelitian yang berbeda, dan dalam objek yang berbeda.

\section{DAFTAR PUSTAKA}

[1] Griffin, Ricky W, Manajemen. Edisi ketujuh. Jakarta: Erlangga, 2004.

[2] Sarinah, dan Mardalena, Pengantar Manajemen. Yogyakarta: Deepublish, 2017.

[3] Project Management Institute, A Guide to the Project Management Body of Knowledge (PMBOK® Guide)-Fifth Edition. Project Management Journal, 44(3), e1$\mathrm{e} 1$, 2013. https://doi.org/10.1002/pmj.21345

[4] Trianto, Mendesaian Model Pembelajaran Inovatif Progresif. Edisi Ke-4. Jakarta: Kencana, 2011. 
[5] V. Gaspersz, Total Quality Management (TQM). Jakarta: PT Gramedia Pustaka Utama, 2006.

[6] T. Sianipar, "Robohnya balkon gedung BEI: 222 gedung Jakarta 'tergolong tak aman'", $B B C$ Indonesia, 2018. https://www.bbc.com/indonesia/d unia-42707133, [diakses: 24 Desember 2020]

[7] V. Gaspersz, Total Quality Management (TQM). Jakarta: PT Gramedia Pustaka Utama, 2005.

[8] Prihantoro, R, Konsep Pengendalian Mutu. Bandung: Remaja Rosdakarya, 2012.

[9] Russell, Roberta S. dan Bernard W. Taylor III, Operations Management. Prentice Hall International, Inc.. New Jersey: Upper Saddle River, 2005.

[10] R. Suardi, Sistem Manajemen Mutu ISO 9001:2000: Penerapannya untuk mencapai TQM. Jakarta: Penerbit PPM, 2001.
[11] Dale, B. G, Managing Quality. USA: Blackwell Publishing, 2007.

[12] D. Wulandari, Putri, "Aplikasi Penerapan Prinsip Evaluasi Kinerja Dan Peningkatan Pada Sistem Manajemen Mutu (SMM) Di Lingkungan Kementrian (PUPR) Berbasis ISO 9001 Tahun 2015 ", 2017.

[13] K. Umam, "Kendala Dalam Menerapkan ISO 9001", Konsultan ISO, 2013. https://konsultaniso.web.id/sistem -manajemen-mutu-iso90012008/kendala-dalammenerapkan-iso-9001/, [diakses: 6 Agustus 2020].

[14] Afuadrizaldi, Standar Baru Sistem Manajemen. Diambil kembali dari Sejarah Perkembangan Standar ISO 9001, 2016.

[15] Sugiyono, Metode Penelitian Kombinasi (Mix Methods). Bandung: Alfabeta, 2017.

[16] Sugiyono, Metode Penelitian Kuantitatif, Kualitatif, dan R\&D. Bandung: Alfabeta, 2015. 


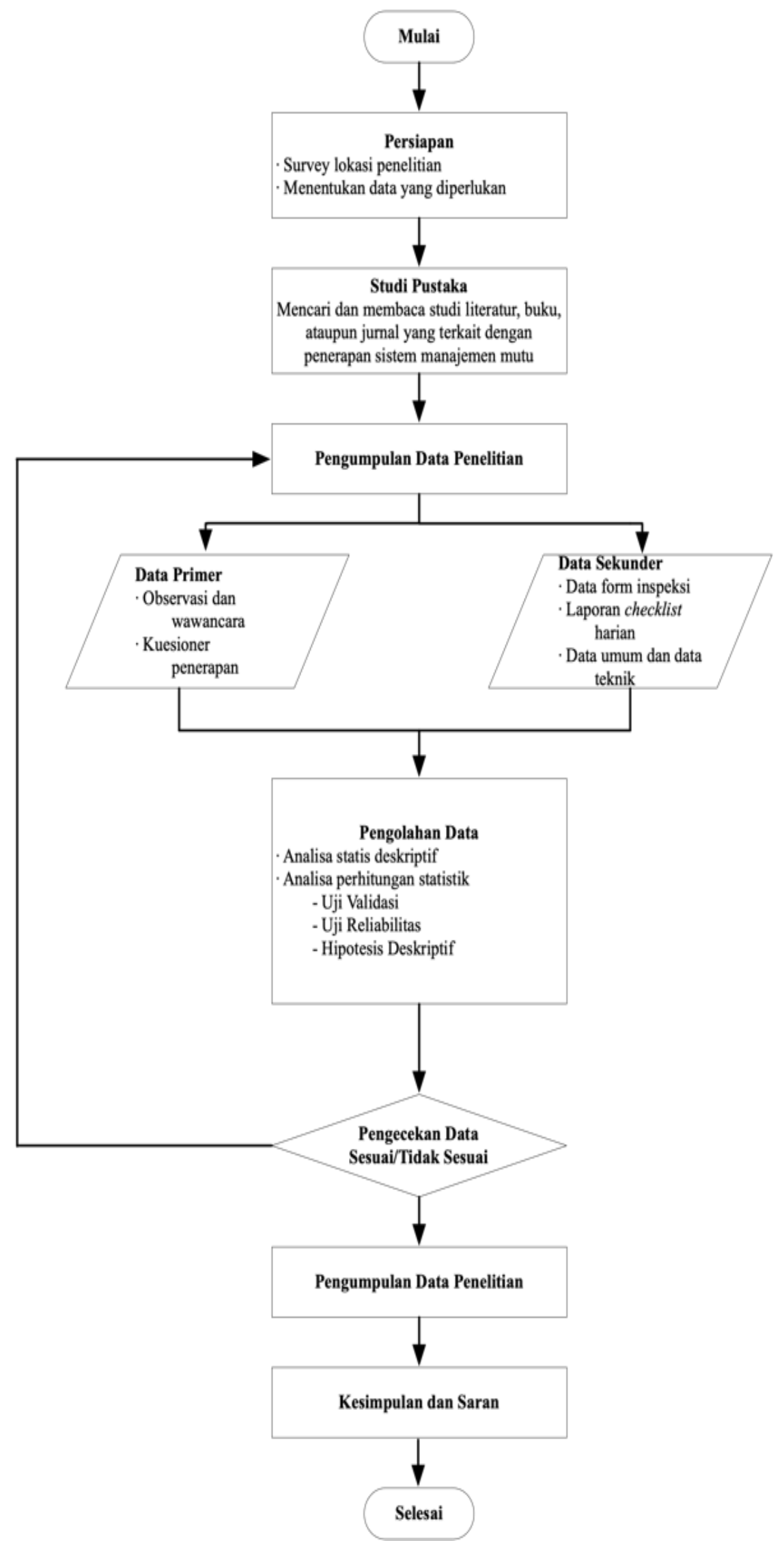

Gambar 1. Diagram Alir Penelitian 
Radar Chart Penerapan Sistem Manajemen Mutu

ISO 9001:2015

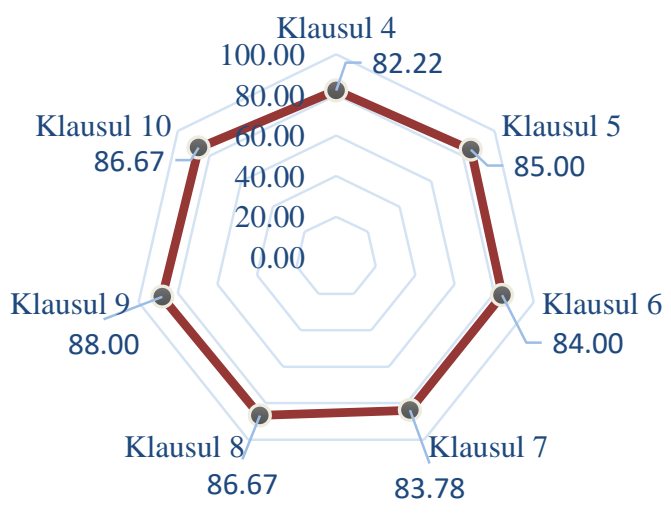

Gambar 2. Radar Chart Penerapan Sistem Manajemen Mutu ISO 9001:2015

$$
\begin{aligned}
& \text { PENGELOMPOKKAN RESPONDEN } \\
& \text { BERDASARKAN JENIS KELAMIN }
\end{aligned}
$$

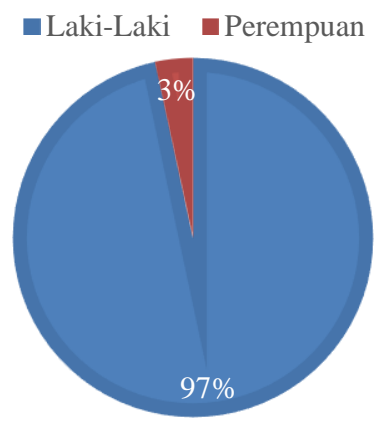

Gambar 3. Pengelompokkan Responden Berdasarkan Jenis Kelamin

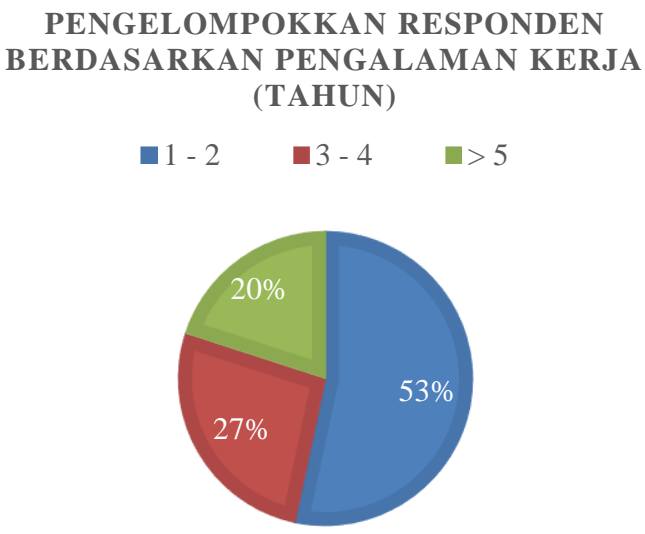

Gambar 4. Pengelompokkan Responden Berdasarkan Pengalaman Kerja 
PENGELOMPOKKAN RESPONDEN

BERDASARKAN TINGKAT PENDIDIKAN

$\square$ SMA / Sederajat

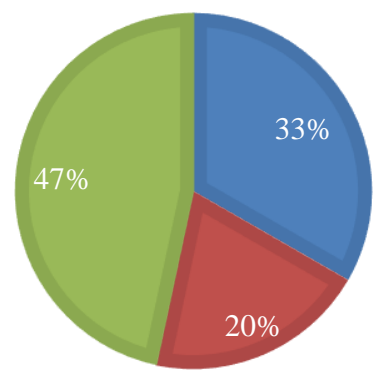

Gambar 5. Pengelompokkan Responden Berdasarkan Tingkat Pendidikan

PENGELOMPOKKAN RESPONDEN

BERDASARKAN DIVISI



Gambar 6. Pengelompokkan Responden Berdasarkan Divisi 
Tabel 1. Hasil Uji Validitas Sistem Manajemen Mutu ISO 9001:2015

\begin{tabular}{ccc}
\hline $\begin{array}{c}\text { Nomor } \\
\text { Butir } \\
\text { Pertany } \\
\text { aan }\end{array}$ & $\begin{array}{c}\text { Pearson } \\
\text { Correlation }\end{array}$ & Keterangan \\
\hline X1.1 & 0,262 & Valid \\
X1.2 & 0,266 & Valid \\
X1.3 & 0,251 & Valid \\
X1.5 & 0,338 & Valid \\
X1.6 & 0,427 & Valid \\
X1.7 & 0,443 & Valid \\
X1.9 & 0,59 & Valid \\
X1.10 & 0,485 & Valid \\
X1.11 & 0,267 & Valid \\
X1.12 & 0,495 & Valid \\
X1.13 & 0,308 & Valid \\
X1.14 & 0,257 & Valid \\
X1.15 & 0,412 & Valid \\
X1.16 & 0,342 & Valid \\
X1.17 & 0,418 & Valid \\
X1.18 & 0,44 & Valid \\
X1.19 & 0,28 & Valid \\
X1.20 & 0,341 & Valid \\
X1.23 & 0,475 & Valid \\
X1.24 & 0,58 & Valid \\
\hline
\end{tabular}

Tabel 2. Hasil Uji Reliabilitas Sistem Manajemen Mutu ISO 9001:2015

\begin{tabular}{ccc}
\hline Variabel & $\begin{array}{c}\text { Cronbach's } \\
\text { Alpha }\end{array}$ & Keterangan \\
\hline $\begin{array}{c}\text { Sistem } \\
\text { Manajemen } \\
\text { Mutu ISO }\end{array}$ & 0,687 & Kuat \\
9001:2015 & & \\
\hline
\end{tabular}


Tabel 3. Hasil Nilai dari One-Sample Statistics

\begin{tabular}{ccccc} 
& N & Mean & $\begin{array}{c}\text { Std. } \\
\text { Deviation }\end{array}$ & \multicolumn{1}{c}{$\begin{array}{c}\text { Std. Error } \\
\text { Mean }\end{array}$} \\
\hline Nilai & 7 & 85,1914 & 2,0223 & 0,76436 \\
\hline
\end{tabular}

Tabel 4. Hasil Nilai dari One-Sample Test

\begin{tabular}{ccccccc}
\hline & & & & & \multicolumn{1}{c}{$\begin{array}{c}\text { 95\% Confidence } \\
\text { Interval of the } \\
\text { Difference }\end{array}$} \\
& $\mathrm{t}$ & df & $\begin{array}{c}\text { Sig. (2- } \\
\text { tailed) }\end{array}$ & $\begin{array}{c}\text { Mean } \\
\text { Difference }\end{array}$ & Lower & Upper \\
\hline Nilai & 5,484 & 6 & 0,002 & 4,19143 & 2,3211 & 6,0617 \\
\hline
\end{tabular}

